\title{
Influence of Edaphic and Phytosociological Attributes on Semideciduous Remnants Vegetation
}

\author{
Maria Teresa Vilela Nogueira Abdo ${ }^{1, *}$, Sergio Valiengo Valeri ${ }^{2}$, Antonio Sergio Ferraudo ${ }^{2}$ \\ ${ }^{1}$ Polo Centro Norte/APTA, Pindorama-SP, Brazil \\ ${ }^{2}$ Faculty of Agrarian and Veterinary Sciences, Campus of Jaboticabal, Paulista State University, Brazil
}

Copyright $(\mathrm{C} 2017$ by authors, all rights reserved. Authors agree that this article remains permanently open access under the terms of the Creative Commons Attribution License 4.0 International License

\begin{abstract}
Atlantic forest biome in Brazil has high biodiversity that is threated due to fragmentation and its remnants retain important residual flora that should be preserved. Studies of environmental conditions that influence species occurrence in those areas are very important to preserve them. This study characterized two remnants vegetation in the Biological Reserve, Pindorama-SP, Brazil, classified as seasonal semideciduous forest sampled in 65 plots of $400 \mathrm{~m}^{2}$, using soil attributes and vegetation data. Soil attributes altitude, basal area, height and number of trees with diameter at breast height $(\mathrm{DBH}) \geq 5 \mathrm{~cm}$ were evaluated in the plots and non-arboreous species infestation was evaluated in a randomly drawn quadrant of $100 \mathrm{~m}^{2}$. The hierarchical clustering, based on soil attributes, separated plots in two major groups and five subgroups of similarity used to characterize the vegetation and the species diversity, by the Shannon Index $\left(\mathrm{H}^{\prime}\right)$ and the Pielou Equitability Coefficient (J). Soil attributes influenced endemic trees and non-arborous vegetation showing that preservation of native vegetation should consider these species relationships. Plots with higher clay percentage and higher fertility had higher infestation of non-arboreous plants as bamboo, lianas and different grasses species and had lower species diversity, basal area and height of tree species.
\end{abstract}

Keywords Toposequence, Soil Vegetation, Biodiversity

\section{Introduction}

The Atlantic forest, after the Amazonian Forest, is the second largest tropical moist forest of South America and extends into tropical and subtropical regions [1]. This forest is very threated due to fragmentation and is represented by a large number of small native remnants with high vegetal biodiversity that should be preserved once it is estimated that there are approximately 20,000 plant species (approximately $35 \%$ of existing species in Brazil) with several endemic and endangered species in those areas [1]. This biome holds great biological diversity corresponding to one of the most important biodiversity niches in the world. The occurrence of these species is conditioned by many edaphic factors, such as climate, soil, altitude, light, water availability, among others. In a forest, the natural landscape of successional mosaics consists of a complex set of relationships that have been studied using different techniques of sampling and evaluation. The species-area relationship present in these mosaics as competition between species for nutrients, water, light and other needs can explain habitat loss and biodiversity loss. Studies that can explain this interrelationship are very important to species knowledge and preservation strategies [1].

The interpretation of data from phytosociological surveys, using techniques of multivariate statistical analysis relating descriptors obtained with edaphic variables, has been conducted by some authors as described below and is very important to preservation of different species in distinct areas. A semi-deciduous forest remnant study in the city of Botucatu-SP-Brazil, using hierarchical classification, obtained a dendrogram with similar plots groups for height, basal area of the individuals and number of individuals, species numbers and area of coverage of the plots [2].

In another study [3] alluvial seasonal deciduous forest remnants in the city of Cachoeira do Sul-RS-Brazil, sample units were classified in distinct groups with similarity for species occurrence of a given group and dissimilarity among the different groups suggesting that environment variation influenced considerably the distribution of the species in the area.

In a study in the city of Ribeirão Preto-SP-Brazil, in 95 remnants, using correspondence analysis and cluster analysis, the existence of three groups with different floristic composition associated to different soils were identified. The vegetation associated with the soils could be subdivided into two subgroups according to the degree of decomposition of the rock: mesophyll forest and deciduous forest, respectively. In areas of Haplortox (LE) and Paleudalf soil the vegetation was typical of "cerradão" and in Hydromorphic soil which 
occur the swamp forest [4].

Soil fertility variation and clay fraction were pointed as relevant factors in determining the vegetation gradient in transition areas between the semi-deciduous and Cerrado Seasonal Forest [5].

A survey of a toposequence in the Maracaju Serra in Aquidauana-MS-Brazil, verified that the larger individuals in diameter and height were found in higher fertility and in deeper soil, where the topography favors the accumulation of sediments during the rainy season [6].

Even areas of great spatial proximity are very diverse and could have very low similarity values [7].

According to some authors [8], the floristic and structural heterogeneity in the floristic formations of the state of São Paulo are determined by the variations of climate and soil. The level of the water table and water availability, determined by the conditions of relief and topography in interaction with soil characteristics, such as soil chemical and physical composition, depth and nutrient cycling, are also indicated as important variables in the composition of the vegetation cover [3] and may be the main distribution factor of tree species in forest formations [5].

Different soils, allied to the moisture gradient and rivers dynamic influence different forest formations in their physiognomy, floristic characteristics, size, structure and composition of the forest fragments. Although this is consensus and variations are detected, there is still a lack of specific correlation information between the different soils and specific variations of the forest formations [9].

The size, shape, use and occupation of soil near the forest remnants besides isolation degree for other forest fragments may influence the vegetation of a fragment up to $100 \mathrm{~m}$ of extension, favoring invasive species due to the presence of light and attributes of soils [10].

The present work had the objective of characterizing the vegetation in the Biological Reserve of Pindorama, SP-Brazil, based on soil physical and chemical attributes and vegetation phytosociological descriptors using multivariate statistics. With the data presented, we intend to contribute to information on the influence of soil attributes on the development of inventoried species and infestation of non-arboreal species, which may be useful in diagnostics and decision making in order to preserve the remnants where they occur.

\section{Materials and Methods}

\subsection{Area Characterization}

The present study was carried out in two forest fragments that are part of the Biological Reserve of Pindorama, which has approximately 144 ha and is located in the Polo Centro Norte - APTA, located in the municipality of Pindorama SP- Brazil. The Reserve was created by Law $N^{0}$. 4,960 dated January 6, 1986 and the forest fragments are constituted of typical vegetation of the Atlantic Forest biome and classified as Tropical Seasonal Semi-deciduous Forest [11].

Figure 1 presents the location of the Polo Centro Norte in São Paulo State, Brazil and the forest remnants evaluated [1].

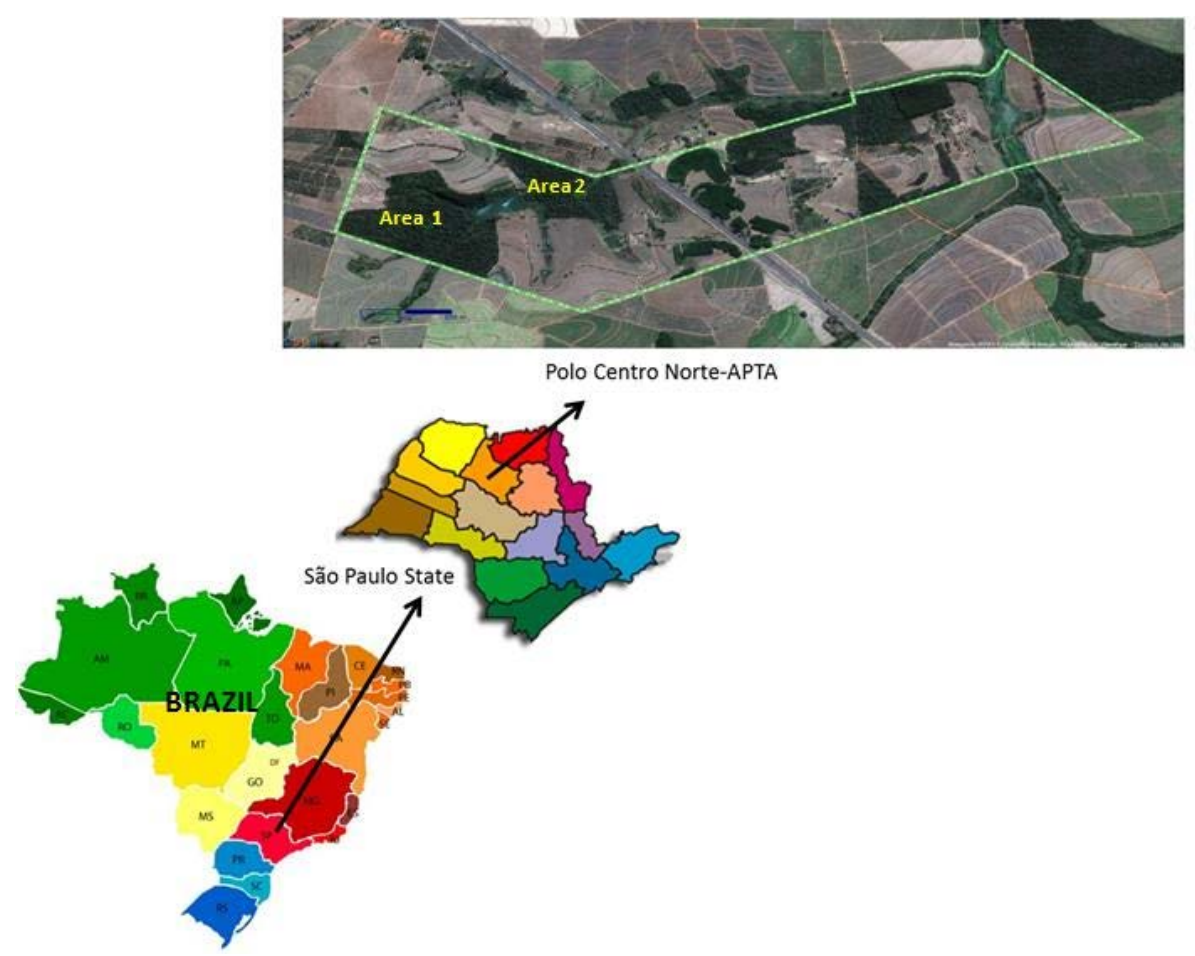

Figure 1. Polo Centro Norte, SP State, Brazil, highlighted in green and localization of surveyed areas with toposequences 1 and 2 highlighted in yellow. [1] 
The Polo Centro Norte is located between the coordinates $48^{\circ} 55$ ' $\mathrm{W}$ and $21^{\circ} 13^{\prime} \mathrm{S}$. The altitude varies from 498 to 594 $\mathrm{m}$ the relief is waved in parts of higher altitudes; passing to soft-waved at lower altitudes with slopes between $2 \%$ and $10 \%$. According to Köppen's classification, the climate is classified as the type AW, defined as tropical humid with rainy season in summer and dry in winter. The average annual rainfall is $1,258 \mathrm{~mm}$, the average temperature of the three summer months is $23.8{ }^{\circ} \mathrm{C}$, and the average winter months are $19.3^{\circ} \mathrm{C}[12]$.

The local soils were first called yellow-red podzolic soil [13] but after 1999 according to classification of soils of Embrapa [14], the soils of the Polo are currently classified as Argisoils of medium / abrupt sandy texture. In the Polo Centro Norte area, six soil units with distinct characteristics were identified: Pindorama, Serrinha, Concreção, Táboa, Jacaíma and Estiva [12].

The present study is in areas of three units, Pindorama, Serrinha and Concreção. The Pindorama and Serrinha soils are deep and well developed and well drained eutrophic, with high base saturation. In the Pindorama Unit the horizon A reaches $50 \mathrm{~cm}$ and the argillic horizon (B textural) around $1 \mathrm{~m}$ with clay contents around 15\% [12]. The Serrinha Unit has an A horizon deeper than $50 \mathrm{~cm}$, reaching $1 \mathrm{~m}$ and the argillic horizon (B textural) with a thickness of about $1 \mathrm{~m}$ may or may not be present. The Concretion Unit corresponds to areas of dystrophic soils, moderately deep, moderately drained and moderately developed, with saturation value around $50 \%$ in horizons A and B and thickness of horizon A around $50 \mathrm{~cm}$.

Sampling was performed in plots of $20 \mathrm{~m} \mathrm{x} 20 \mathrm{~m}$ distributed in two transects 1 and 2 of the forest fragment, based on Tabanez [10], each involving a toposequence. The toposequence 1 is located in eutrophic soils, in the Serrinha and Pindorama units with 43 plots and the toposequence 2 is located only in the dystrophic soil area, in the Concretion unit with 22 demarcated plots.

A $10 \mathrm{~m} \times 10 \mathrm{~m}$ quadrant was randomly drawn for the characterization of arboreal individuals with breast height diameter $(\mathrm{DBH}) \geq 5 \mathrm{~cm}$, and collection of material for soil analysis. The size of the sampled plots was evaluated for sample adequacy based on the species / area ratio curve [15]. For the evaluation of non-arboreous weed plants, the total plot of $20 \mathrm{~m}$ x $20 \mathrm{~m}$ was considered.

\subsection{Soil Collecting and Assessment}

The physical and chemical analyzes of the soil at $0-20 \mathrm{~cm}$ were performed in each plot of samples composed of 20 sub-samples within the drawn quadrant $\left(100 \mathrm{~m}^{2}\right)$. After drying in the air and obtaining the fine dry earth in the air, the following analyzes were carried out: granulometry, by the densimeter method; $\mathrm{PH}$ in $\mathrm{CaCl}_{2}$ (mol L-1); Organic matter (OM); Phosphorus, potassium, calcium and magnesium by the ion exchange resin method; Acidity $(\mathrm{H}+\mathrm{Al})$ by the calcium acetate method $1 \mathrm{~mol} \mathrm{~L}-1$. Base saturation (V\%) was calculated according to Raij [16].

\subsection{Phytosociological Survey}

In the $100 \mathrm{~m}^{2}$ randomly drawn quadrant, the identification of the plot and of the individual was identified by a metal plates, the live trees with DBH (diameter at the breast high) $\geq$ $5 \mathrm{~cm}$, the diameter being recorded and the material collected Botanical for identification. The material was herborized and the identification was done using keys of identification and comparison with exicates in the Horto of UNESP - Campus of São José do Rio Preto and Jaboticabal campus.

The following phytosociological descriptors were calculated: absolute density (ADi) = Ni / A; Relative density $(\mathrm{RDi})=100 \mathrm{Ni} / \mathrm{N}$; Relative dominance $(\mathrm{RDo})=(\mathrm{DBHi} /$ DBHt) 100; Absolute frequency of the species (AFi) $=100 *$ (pi / P); Relative frequency $(\mathrm{RF})=100 *(\mathrm{AFi} / \mathrm{\Sigma AF})$; Value of importance $(\mathrm{VI})=(\mathrm{RDi}+\mathrm{RDo}+\mathrm{RF})$. Where, $\mathrm{Ni}=$ number of individuals of the species, $\mathrm{A}=$ total area lifted, $\mathrm{N}$ $=$ number of individuals total of the survey, $\mathrm{BAi}=$ basal area of all individuals of the species e, BAt $=$ basal area of all identified individuals, $\mathrm{Pi}=$ number of plots where the species "i" was found and $\mathrm{P}$ is the total number of plots of $10 \mathrm{~m} \times 10$ $\mathrm{m}$.

These data were necessary for the analysis of the diversity of the tree species of the plot groups calculated by the Shannon Diversity Index ( $\left.\mathrm{H}^{\prime}\right)$ :

$\mathrm{H}^{\prime}=\Sigma \mathrm{Pi} \cdot \ln (\mathrm{Pi})$ Where: $\mathrm{Pi}$ is the number of individuals of species i / Total number of individuals, $\ln$ is logarithm neperian;

H'max = lnS where $\mathrm{H}^{\prime}=$ Shannon diversity index of the area, Hmax $=\ln (S)$, where $S$ is the number of species sampled and $\ln =$ logarithm neperian.

And the coefficient of Equability of Pielou ( $\mathrm{J}$ ) used to indicate the uniformity of the distribution of the species in a certain area:

$$
\mathrm{J}=\mathrm{H}^{\prime} / \mathrm{H} \max
$$

\subsection{Evaluation of Degree of Infestation by Non-Arboreal Plants in the Plot in plots of $20 \mathrm{~m} \times 20 \mathrm{~m}$}

We adopted 10 classes of infestation ranging from null (zero) to completely infested (ten), according to an assessment of the area coverage percentage by noting all non-tree plants (lianas, bamboo, grass colonies, sugarcane [17].

\subsection{Statistical Analysis}

The plots were compared using the physical (clay and total sand) and chemical (ph, organic matter, P, K, Ca, Mg and H $+\mathrm{Al}$, and base saturation) attributes of the soils by multivariate statistical analysis, and grouping by hierarchical method, using Euclidean distance as a measure of similarity and Ward's method as a linking algorithm between groups [18]. Statistica, version 7.0 [19]. 
The mean values of soil attributes such as clay and total sand contents, $\mathrm{pH}$, organic matter, $\mathrm{P}, \mathrm{K}, \mathrm{Ca}, \mathrm{Mg}$ and $\mathrm{H}+$ contents were calculated after adoption of the groups of similar plots suggested by the dendrogram grouping analysis. $\mathrm{Al}$, and base saturation, infestation of non-arboreal plants and determined the Shannon Index $\left(\mathrm{H}^{\prime}\right)$ and the Pielou Equability Coefficient (J) for each of the groups. Subsequently the means of the groups were compared by the Tukey test, $5 \%$ probability, to verify if there was significant difference between the groups. These ANOVA tests were performed using the ASSISTAT Software version 7.7.

\section{Results and Discussion}

The species identified in the two fragments and their respective families are presented in Table 1 . During the survey in toposequence 1 (A1) and toposequence 2 (A2) 572 trees individuals from 33 families were identified [11].

Table 1. Families, scientific and common name and number of individuals identified in fragment 1 (A1) and fragment 2 (A2) of the remaining semideciduous seasonal forest of the Biological Reserve of Pindorama-SP, Brazil

\begin{tabular}{|c|c|c|c|}
\hline FAMILY AND SPECIE NAMES & Common name & $\mathbf{A 1}$ & A2 \\
\hline \multicolumn{4}{|l|}{ ADOXACEAE } \\
\hline Sambucus australis Cham. \& Schltdl. & sabugueiro & 1 & 0 \\
\hline \multicolumn{4}{|l|}{ ANACARDIACEAE } \\
\hline Astronium graveolens Jacq. & guarita & 49 & 23 \\
\hline Mangifera indica L. & manga & 0 & 1 \\
\hline Rollinia sylvatica (A. St.-Hil.)Mart. & araticum- do- mato & 1 & 0 \\
\hline Annona cacans Warm & araticum & 0 & 4 \\
\hline Duguetia lanceolata A.St.-Hill & pindaíba & 0 & 5 \\
\hline \multicolumn{4}{|l|}{ APOCYNACEAE } \\
\hline Aspidosperma polyneuron Müll. Arg. & peroba-rosa & 6 & 5 \\
\hline Aspidosperma cylindrocarpon Müll. Arg. & peroba-poca & 1 & 1 \\
\hline \multicolumn{4}{|l|}{ ARALIACEAE } \\
\hline Sciadodendron excelsum Griseb. & carobão & 1 & 0 \\
\hline Dendropanax cuneatus Decne. \& Planch. & maria- mole & 6 & 0 \\
\hline Didymopanax morototoni (Aubl.) Decne. Planch. & mandiocão & 0 & 1 \\
\hline \multicolumn{4}{|l|}{ ARECACEAE (PALMAE) } \\
\hline Syagrus oleraceae Becc. & palmeira-guariroba & 3 & 0 \\
\hline Syagrus romanzoffiana (Cham.) Glassman & jerivá & 0 & 1 \\
\hline \multicolumn{4}{|l|}{ BIGNONIACEAE } \\
\hline Zeyheria tuberculosa Bureau & ipê- felpudo & 1 & 0 \\
\hline \multicolumn{4}{|l|}{ BURSERACEAE } \\
\hline Protium heptaphyllum L. Marchand & almecegueira & 1 & 0 \\
\hline \multicolumn{4}{|l|}{ CARICACEAE } \\
\hline Jacaratia spinosa (Aubl.) A. DC. & jaracatiá & 1 & 3 \\
\hline \multicolumn{4}{|l|}{ CLUSIACEAE (GUTTIFERAE) } \\
\hline Calophyllum brasiliense Cambess. & guanandi & 0 & 1 \\
\hline Garcinia gardneriana Planch. \& Triana & bacupari & 0 & 1 \\
\hline \multicolumn{4}{|l|}{ EUPHORBIACEAE } \\
\hline Alchornea triplinervia (Spreng) Müll. Arg. & pau-jangada & 5 & 3 \\
\hline Croton floribundus Spreng. & capixingui & 12 & 15 \\
\hline Hura crepitans L. & assapu & 1 & 0 \\
\hline \multicolumn{4}{|l|}{ FABACEAE (LEGUMINOSAE) } \\
\hline Acacia polyphylla DC. & monjoleiro & 27 & 2 \\
\hline Albizia hasslerii (Chodat) Burkart & farinha -seca & 6 & 2 \\
\hline Bauhinia sp. & unha-de-vaca & 0 & 1 \\
\hline Copaifera langsdorffii Desf & copaíba & 0 & 2 \\
\hline
\end{tabular}




\begin{tabular}{|c|c|c|c|}
\hline Enterolobium contortisiliquum (Vell.) Morong & tamburil & 0 & 2 \\
\hline Hymenaea courbaril L. & jatobá & 1 & 1 \\
\hline Inga vera Willd. & ingá & 2 & 1 \\
\hline Machaerium paraguariense Hassl. & jacarandá- branco & 14 & 0 \\
\hline Machaerium stipitatum Vogel & sapuva & 19 & 7 \\
\hline Myrocarpus frondosus Allem. & cabreúva & 3 & 4 \\
\hline Peltophorum dubium (Spreng) Taub. & canafístula & 0 & 1 \\
\hline \multicolumn{4}{|l|}{ LAMIACEAE (LABIATAE) } \\
\hline Vitex montevidensis Cham & tarumã & 2 & 0 \\
\hline \multicolumn{4}{|l|}{ LAURACEAE } \\
\hline Cinnamoтum camphora (L.) J. Presl. & cânfora & 4 & 0 \\
\hline Nectandra salicifolia & nectandra & 1 & 0 \\
\hline Nectandra venulosa Meisn. & canelinha & 0 & 3 \\
\hline Ocotea velutina (Nees) Rohwer & canelão & 3 & 6 \\
\hline Cariniana estrellensis (Raddi) Kuntze & jequitibá-branco & 4 & 1 \\
\hline \multicolumn{4}{|l|}{ MALVACEAE } \\
\hline Ceiba speciosa (A. St.-Hil., A.Juss \& Cambess.) Ravenna & paineira & 9 & 2 \\
\hline Guazuma ulmifolia Lam. & mutambo & 1 & 0 \\
\hline Heliocarpus americanus L. & algodoeira & 1 & 0 \\
\hline \multicolumn{4}{|l|}{ MELASTOMATACEAE } \\
\hline Tibouchina granulosa (Desr.) Cogn. & quaresmeira & 2 & 5 \\
\hline \multicolumn{4}{|l|}{ MELIACEAE } \\
\hline Cedrela fissilis Vell. & cedro & 1 & 1 \\
\hline Guarea guidonia (L.) Sleumer & marinheiro & 1 & 8 \\
\hline Guarea kunthiana A. Juss & canjambo & 3 & 24 \\
\hline Guarea macrophylla Vahl & peloteiro & 4 & 18 \\
\hline Trichilia catigua A. Juss. & catiguá & 12 & 14 \\
\hline Trichilia claussenii C. DC. & catiguá- vermelho & 15 & 0 \\
\hline \multicolumn{4}{|l|}{ MORACEAE } \\
\hline Brosimum gaudichaudii Trécul & mamica-de- cadela & 0 & 3 \\
\hline Ficus insipida Willd. & figueira & 1 & 0 \\
\hline Maclura tinctoria (L.) D. Don ex Steud. & taiúva & 1 & 0 \\
\hline \multicolumn{4}{|l|}{ MYRTACEAE } \\
\hline Campomanesia guazumaefolia (Cambess.) O. Berg & sete- capotes & 0 & 1 \\
\hline Campomanesia xanthocarpa O. Berg. & guariroba & 3 & 0 \\
\hline Eugenia florida DC. & pitanga-preta & 0 & 1 \\
\hline Eugenia uniflora L. & pitanga & 3 & 9 \\
\hline Myrciaria glomerata O. Berg & cabeludinha & 0 & 1 \\
\hline Myrciaria trunciflora O. Berg & jabuticaba & 1 & 0 \\
\hline Myrtaceae sp. & myrtaceae & 1 & 0 \\
\hline Syzygium cumini (L.) Skeels & jambolão & 2 & 0 \\
\hline Syzygium jambos (L.) Alston & jambo & 0 & 1 \\
\hline \multicolumn{4}{|l|}{ NYCTAGINACEAE } \\
\hline Bougainvillea glabra Choisy & primavera-arbórea & 6 & 0 \\
\hline \multicolumn{4}{|l|}{ PAPILIONOIDEAE } \\
\hline Machaerium acutifolium Mart. ex Benth & jacarandá & 9 & 6 \\
\hline PHYTOLACCACEAE & & & \\
\hline
\end{tabular}




\begin{tabular}{|c|c|c|c|}
\hline Gallesia gorazema Moq. & pau- d’álho & 2 & 0 \\
\hline \multicolumn{4}{|l|}{ PIPERACEAE } \\
\hline Piper L. & piper & 1 & 1 \\
\hline \multicolumn{4}{|l|}{ PROTEACEAE } \\
\hline Roupala brasiliensis Klotzsch & carvalho & 2 & 1 \\
\hline \multicolumn{4}{|l|}{ RHAMNACEAE } \\
\hline Colubrina glandulosa Perkins. & sobrasil & 1 & 7 \\
\hline Colubrina rufa Perkins. & saguaragi & 0 & 1 \\
\hline Rhamnidium elaeocarpum Reissek & cafezinho & 0 & 2 \\
\hline \multicolumn{4}{|l|}{ RUBIACEAE } \\
\hline Guettarda viburnoides Cham. \& Schltdl & veludinha & 1 & 0 \\
\hline \multicolumn{4}{|l|}{ RUTACEAE } \\
\hline Balfourodendron riedelianum (Engl.) Engl. & pau-marfim & 32 & 9 \\
\hline \multicolumn{4}{|l|}{ SALICACEAE } \\
\hline Casearia gossypiosperma Briq. & espeteiro & 20 & 2 \\
\hline Casearia sylvestris Sw. & guaçatonga & 12 & 0 \\
\hline \multicolumn{4}{|l|}{ SOLANACEAE } \\
\hline Sessea brasiliensis Toledo & peroba-d’água & 2 & 0 \\
\hline \multicolumn{4}{|l|}{ URTICACEAE } \\
\hline Cecropia pachystachya Trécul & embaúba & 1 & 1 \\
\hline \multicolumn{4}{|l|}{ VERBENACEAE } \\
\hline Aloysia virgata (Ruiz \& Pav.) Pers. & lixa & 14 & 1 \\
\hline \multicolumn{4}{|l|}{ VOCHYSIASEAE } \\
\hline Vochysia tucanorum (Spr.) Mart & pau- cinzeiro & 0 & 3 \\
\hline \multicolumn{4}{|l|}{ UNIDENTIFIED } \\
\hline unidentified 1 & & 8 & 0 \\
\hline unidentified 2 & & 0 & 1 \\
\hline & Total & 351 & 221 \\
\hline
\end{tabular}

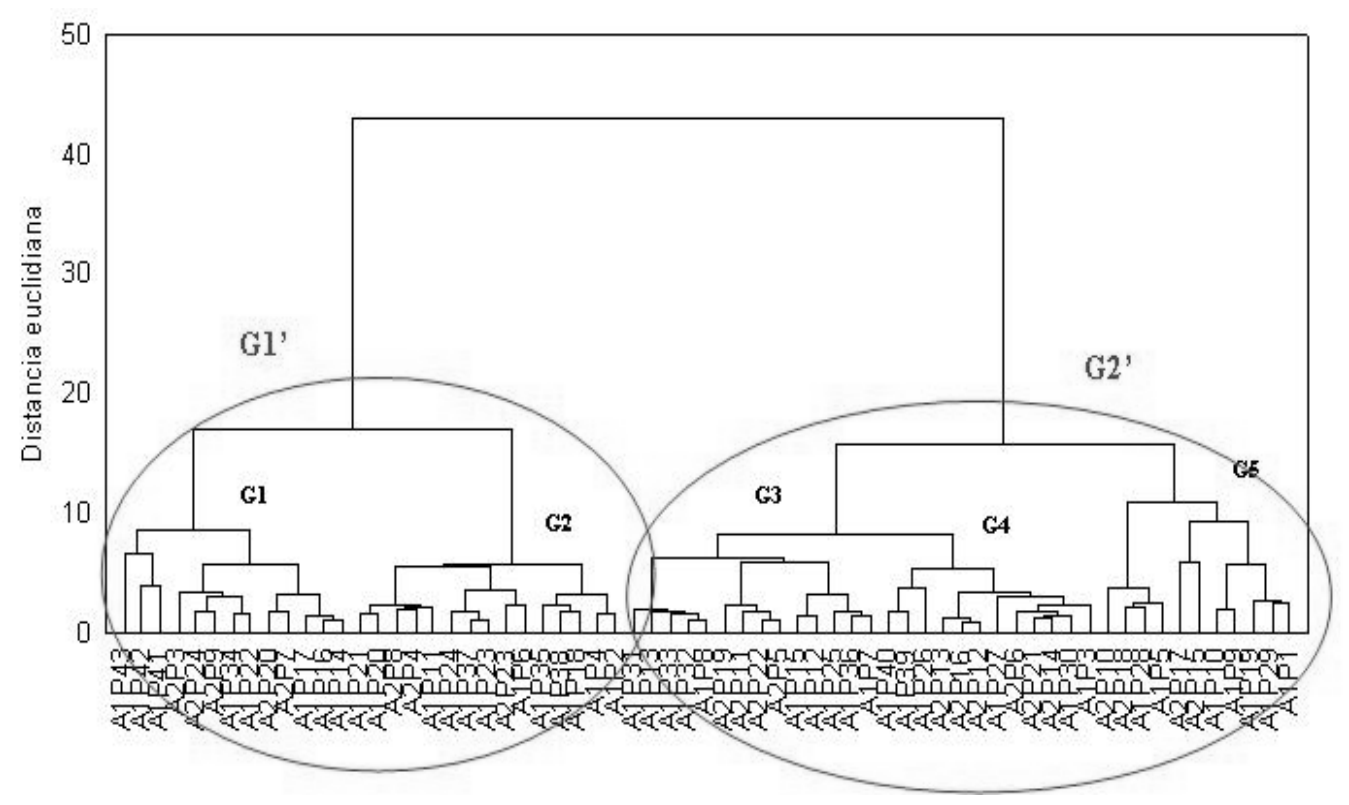

Figure 2. Dendrogram with the structure of two parcels groups - G1' e G2' and 5 sub-groups (G1, G2, G3, G4 e G5) based on soil attributes in two toposequences (A1 and A2) of Tropical Forest, Pindorama Biological Reserve, Pindorama-SP-Brazil. 


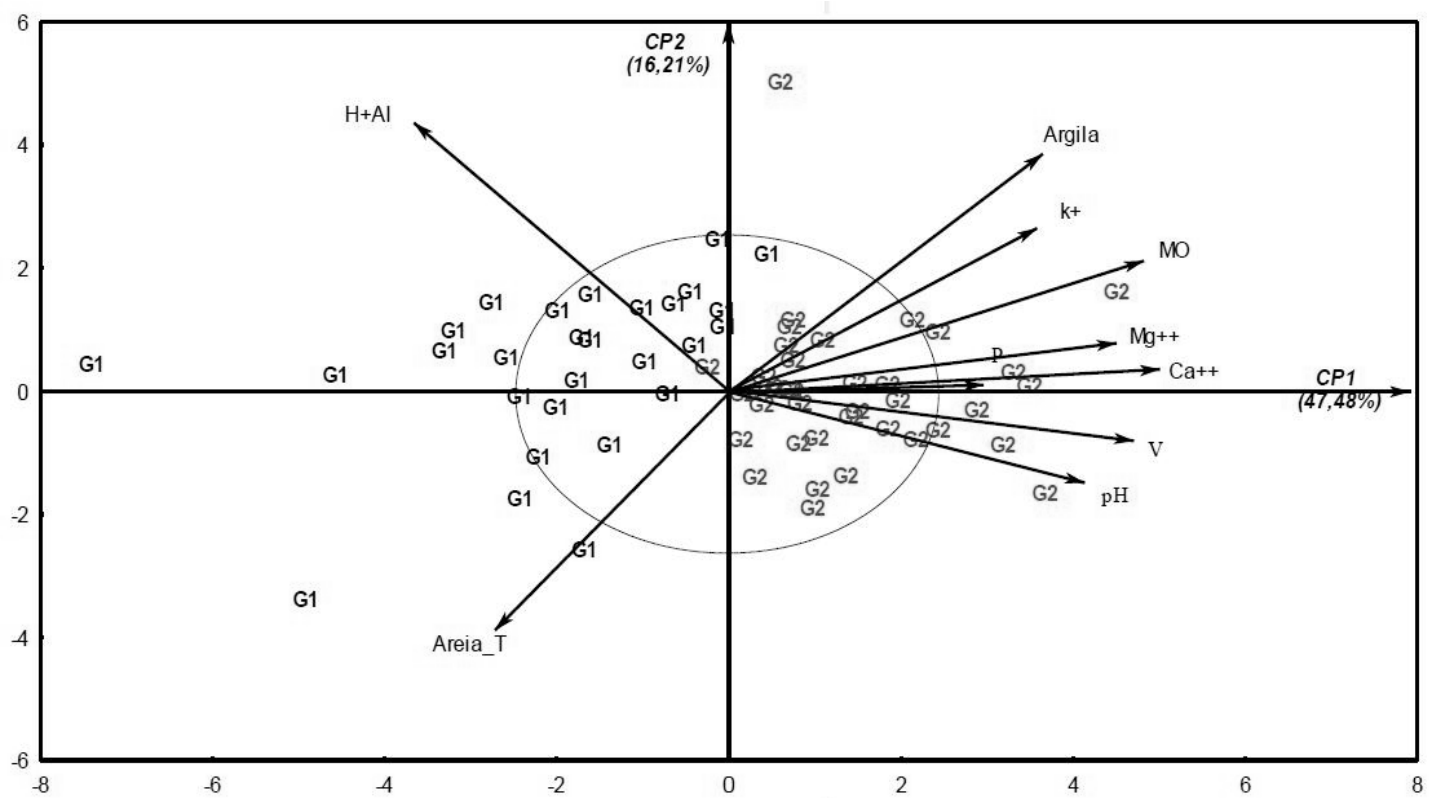

Figure 3. Biplot graphic of principal components 1 and 2 showing the parcels distribution (G1' e G2') and the correlation to soil attributes.

The plots were identified according to the location area toposequence 1 (A1) and toposequence 2 (A2) and sequential numbers for the identification of plots (P1 to Pn) (Figure 2).

After soil and vegetation data analysis using multivariate statistic a dendrogram was generated (Figure 2) and made it possible to group the plots into two groups: similarity between the plots of the same group (G1 'and G2') and dissimilarity between the plots from different groups. Initially, plots groups were adopted according to soil attributes, where G1 'was composed of G1 and G2; And G2' composed of G3, G4 and G5 of the dendrogram (Figure 2).

In an attempt to group plots with similar attributes, the hierarchical grouping analysis was used by the Ward method, which showed that there was a variation in the soil of the plots located in the two topossequences evaluated since the dendrogram generated them in two large groups (G1' and G2') and five subgroups (G1, G2, G3, G4 and G5) based on the variables of soil fertility and granulometry.

Initially, it was adopted the division into two groups of plots making considerations regarding these groups. Subsequently, the number of five groups was adopted and for each group the average values of vegetation characteristics were determined. The principal component analysis provides a structural simplification of the original data and in the analyzed data the first two main components explain $63.69 \%$ of the variance (CP1 47.48\% and CP2 16.21\%) explaining satisfactorily the variability manifested between the plots evaluated, Simplifying interpretation.

The biplot graph of the information contained in the variables was constructed from the first two main components (Figure 3).

The plots of group 1' are located more to the left in CP1 and the plots of group 2' are located to the right (Figure 2).
The plots of group G1 'are more associated with the soils with more sand and with higher exchangeable acidity $(\mathrm{H}+$ $\mathrm{Al}$ ), whereas the sample units of group G2' are associated with $\mathrm{V} \%, \mathrm{Ca}++, \mathrm{Mg}++$ and matter Organic.

In the first component, the variables with higher discriminatory power were total sand, clay, V\%, Ca, organic matter, $\mathrm{P}, \mathrm{pH}, \mathrm{Mg}, \mathrm{K}, \mathrm{H}+\mathrm{Al}$ with negative correlations, contrasting with infestation of non - arboreous plants of positive correlation. In the second main component, the variables with higher discriminatory power were $\mathrm{P}, \mathrm{pH}$, organic matter, $\mathrm{K}$, clay, $\mathrm{Mg}, \mathrm{Ca}, \mathrm{H}+\mathrm{Al}$, infestation and V\% with negative correlation, contrasting with total sand of positive correlation (Table 2).

Table 2. Correlation between each vegetation characteristic and a principal component, where $\mathrm{TS}=$ total sand, $\mathrm{P}=$ phosphorus, $\mathrm{OM}=$ organic matter, $\mathrm{K}$ = potassium, $\mathrm{Ca}=$ calcium, $\mathrm{Mg}=$ magnesium, $\mathrm{H}+\mathrm{Al}=$ potencial acidity, $\mathrm{V}=$ base saturation and Infest = Infestation. in numerical order.

\begin{tabular}{|c|c|c|}
\hline CHARATERÍSTIC & CP1 & CP2 \\
\hline Clay & $-1,60638$ & $-1,09751$ \\
\hline TS & $-7,18112$ & 1,43757 \\
\hline $\mathrm{P}$ & $-0,22275$ & $-1,43890$ \\
\hline $\mathrm{pH}$ & $-0,16649$ & $-1,33524$ \\
\hline $\mathrm{OM}$ & $-0,33279$ & $-1,13563$ \\
\hline $\mathrm{K}+$ & $-0,04114$ & $-1,13354$ \\
\hline $\mathrm{Ca}$ & $-0,59860$ & $-0,76510$ \\
\hline $\mathrm{Mg}$ & $-0,06695$ & $-0,86657$ \\
\hline $\mathrm{H}+\mathrm{Al}$ & $-0,00584$ & $-0,76509$ \\
\hline $\mathrm{V}$ & $-0,61204$ & $-0,37542$ \\
\hline Infest & 0,15887 & $-0,58036$ \\
\hline
\end{tabular}


Table 3. Variation Coefficients (CV), General Mean (MG) and means of soil attributes variables in each parcel group (G1 at G5).

\begin{tabular}{|c|c|c|c|c|c|c|c|c|c|c|c|}
\hline \multirow{2}{*}{ Groups } & Clay & Sand & $\mathrm{P}$ & \multirow{2}{*}{$\frac{\mathrm{pH}}{\mathrm{CaCl}_{2}}$} & & & $\mathrm{Ca}^{+}$ & $\mathrm{Mg}^{2+}$ & $\mathrm{H}+\mathrm{Al}$ & \multirow{2}{*}{$\begin{array}{l}\mathrm{V} \\
\% \\
\end{array}$} & \multirow[t]{2}{*}{ Infestation } \\
\hline & \multicolumn{3}{|c|}{ 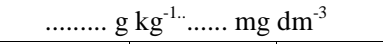 } & & \multicolumn{5}{|c|}{ 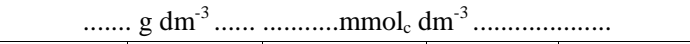 } & & \\
\hline VC \% & 10,58 & 4,40 & 26,74 & 4,44 & 15,03 & 86,96 & 16,88 & 21,14 & 16,83 & 4,78 & 41,58 \\
\hline GM & 144,92 & 773,83 & 5,96 & 6,03 & 25,98 & 2,62 & 58,95 & 13,72 & 15,18 & 82,29 & 5,95 \\
\hline G1 & $124,07 \mathrm{~b}$ & 815,53 a & $4,84 \mathrm{~b}$ & $5,60 \mathrm{~b}$ & $20,07 \mathrm{~d}$ & $1,75 \mathrm{a}$ & 37,15 c & 10,53 c & 17,23 а & 73,67 c & 5,53 а \\
\hline G2 & 157,06 a & $752,60 \mathrm{bc}$ & $5,06 \mathrm{~b}$ & $5,78 \mathrm{~b}$ & $24,13 \mathrm{~cd}$ & $2,06 \mathrm{a}$ & $56,73 \mathrm{~b}$ & 12,06 bc & 17,40 a & $80,20 \mathrm{~b}$ & $5,80 \mathrm{a}$ \\
\hline G3 & 142,57 a & $774,21 \mathrm{bc}$ & $5,35 \mathrm{~b}$ & 6,40 a & 26,35 bc & 2,59 a & $63,21 \mathrm{ab}$ & $15,07 \mathrm{ab}$ & 12,07 b & 86,82 a & 5,64 a \\
\hline G4 & $148,00 \mathrm{a}$ & $789,08 \mathrm{ab}$ & $5,75 \mathrm{~b}$ & $6,11 \mathrm{a}$ & 31,08 a & $2,20 \mathrm{a}$ & 69,75 a & 15,75 a & $14,66 \mathrm{ab}$ & 85,62 a & 7,25 a \\
\hline G5 & 152,63 a & 736,36 c & 9,54 a & 6,29 a & $29,45 \mathrm{ab}$ & 3,23 a & 70,54 a & 15,81 а & 14,27 b & 85,92 а & 5,63 a \\
\hline
\end{tabular}

Means followed by the same letter do not differ statistically from each other. The Tukey test was applied at the 5\% probability level.

For a more detailed analysis of the plots, the division into five dendrogram similarity subgroups (G1, G2, G3, G4, and G5) was adopted, maximizing the similarity between plots in the group.

In this second analysis of the groups the averages of the physical and chemical attributes of the soil were compared by applying the Tukey test to the $5 \%$ probability level (Table 3).

In order to verify if the variability of the soil attributes of the plots influences the composition of the vegetation in the subgroups and their distribution in the plots, the average of the plots altitude and the following phytosociological descriptors were recalculated for each of the 5 subgroups: number of species (S), number of individuals per hectare (Niha-1), mean basal area per hectare of all individuals (G ha-1), importance value, Shannon Index ( $\mathrm{H}$ ') and Pielou Equability Coefficient ) Of the tree community, as well as the degree of infestation of invasive plants (Inf) (Table 4).

According to the classification of Raij [16], the groups presented low acidity (groups 1 and 2) and very low (groups 3, 4 and 5), within the appropriate limits for the development of forest species. Based on these authors, all groups of plots presented average levels of Organic Matter (between 20.1 and $40.00 \mathrm{~g} / \mathrm{kg}$ or $\mathrm{g} / \mathrm{dm}^{3}$ ) and low values for available phosphorus, except for group 5 that presented a $\mathrm{P}$ as the low availability range of phosphorus obtained by the resin values of $0-8 \mathrm{mg} / \mathrm{dm}^{3}$ for forest species and high for values above 9 $\mathrm{mg} / \mathrm{dm}^{3}[16]$.

Some considerations about the soil of each group of plots and the vegetation present in them can be done:

Group 1: Parcels located on land with lower levels and statistically lower values of clay, organic matter, Ca and V\% and higher $\mathrm{H}+\mathrm{Al}$, therefore of lower fertility. As the lowest $\mathrm{P}$ content and the lowest basal area of the species, it presents a number of species below the average of the groups, but above the average number of individuals per hectare, diversity of species and equability index. High tree density and low basal area may be associated with low levels of invasive plant infestation or edge effect as a consequence of low fertility.

Group 2: Higher plots of land and drier soil. High clay content, which similar to Group 1, with values statistically below the mean of Groups 3, 4 and 5 for P, pH, OM, K, Ca,
$\mathrm{Mg}, \mathrm{V}$ and $\mathrm{H}+\mathrm{Al}$ values above the mean. Lower number of individuals per hectare, higher basal area and average height, low degree of infestation of grasses and lianas and less competition for light water and nutrients. The highest values of $\mathrm{H}$ 'occurred in Groups 1 and 2, suggesting that infestation by invasive plants directly affects the diversity of species in the area but the soil acidity does not.

Group 3: Parcels of higher parts differing statistically from Group 1 in the clay content and Groups 1, 4 and 5 in the sand content. Statistically higher values of Groups 1 and 2 for $\mathrm{pH}$, $\mathrm{OM}, \mathrm{Ca}, \mathrm{Mg}$, and higher $\mathrm{V} \%$ and lower $\mathrm{H}+\mathrm{Al}$. It has the highest value of identified species and individuals per hectare and total basal area, and species diversity ( $\left.\mathrm{H}^{\prime}\right)$ and low equability (J). Mean value of infestation of invasive plants, but lower than Group 4 and the highest basal area, probably due to good fertility with high V\%.

Group 4: Lower plots and subject to waterlogging. Statistically of sandy soils, low P content and high OM and $\mathrm{V} \%$. They are soils of good fertility and higher rate of organic matter but with lower total basal area of the species and low $\mathrm{H}$ 'and coefficient equability probably due to the degree of infestation favored by high soil fertility.

Group 5: Parcels located in high and dry parts. High numbers and diversity of species $(\mathrm{H}$ ') and equability index (J), but few individuals per hectare and total basal area. The high fertility seems to favor several species, but with less development in relation to the trees of Groups 1, 2 and 3.

The diversity of species ( $\mathrm{H}$ ') presented was higher than the values found in studies carried out in the state of São Paulo in Luiz Antônio [20], which are similar to the highest values of $\mathrm{H}$ 'obtained for Atlantic Forest [8]. In addition to the low phosphorus content in groups 1,2 and 3 there is no limitation for the development of tree species of Atlantic Forest biome [16].

G1 and G2 and even low acidity groups G3, G4 and G5 presented adequate values for forest species [21]. What is observed is that the group that presented highest infestation by non-arboreal plants is the group 4 had higher content of organic matter. This group had the lowest number of tree species, the lowest basal area of the tree species and the lowest diversity index ( $\left.\mathrm{H}^{\prime}\right)$, suggesting that invasive species, which occupy plots of more fertile soils, have a negative influence on the occurrence and growth of arboreal species. 
Table 4. Altitudes, number of species $(\mathrm{S})$ and number of individuals per hectare $\left(\mathrm{Ni} \mathrm{ha}^{-1}\right)$, total basal area $(\mathrm{G})$, diversity index $\left(\mathrm{H}^{\prime}\right)$ and equability index $(\mathrm{J})$ of tree species (DBH $\geq 5 \mathrm{~cm}$ ) and infestation by non-arborous vegetation (Inf) in each parcel group.

\begin{tabular}{|c|c|c|c|c|c|c|c|}
\hline Groups & Altitude (m) & $\mathrm{S}$ & $\mathrm{Ni} \mathrm{ha}^{-1}$ & $\mathrm{G} \mathrm{m}^{2} \mathrm{ha}^{-1}$ & $\mathrm{H}$ & $\mathrm{J}$ & $\mathrm{Inf}$ \\
\hline $\mathrm{G} 1$ & 559,02 & 36,0 & 930,7 & 2,91560 & 3,29 & 0,91 & 5,53 \\
\hline G2 & 573,30 & 39,0 & 720,0 & 2,85413 & 3,28 & 0,88 & 5,80 \\
\hline G3 & 568,74 & 39,0 & 1092,8 & 3,19391 & 3,21 & 0,87 & 5,64 \\
\hline G4 & 556,14 & 36,0 & 816,6 & 1,60197 & 3,17 & 0,85 & 7,25 \\
\hline G5 & 569,88 & 38,0 & 809,0 & 1,85156 & 3,30 & 0,89 & 5,60 \\
\hline Mean & 565,45 & 37,3 & 873,8 & 2,48343 & 3,25 & 0,88 & 5,96 \\
\hline
\end{tabular}

This inverse relationship is also observed in Group 1, which is the group with the lowest infestation of non-arboreal plants, lower organic matter content and lower $\mathrm{V} \%$, which presents a high basal area value of tree species and diversity ( $\mathrm{H}$ ').

It can be noticed that there is diversity in the attributes of soils, in the vegetation of the place and occurrence of non-arboreal invasive species and the values suggest a correlation between these variables. Soil fertility and organic matter contents positively interfere with the occurrence of non-arboreal species and when these species tend to colonize an area, lower values for diversity and tree species growth are observed.

The evaluated forest fragments presented a diversity of species within average values for the state of São Paulo [7] [8].

\section{Conclusions}

Edaphic factors are relevant to forest fragments preservation once they influence the occurrence and growth of arboreal species and non-arboreal species.

Low soil fertility leads to low infestation of invasive plants in plots whose infestation reduces species diversity, basal area and mean height of native forest species in forest fragments.

Data on the occurrence and growth of native tree species and their correlations with edaphic factors are useful for recommending planting under specific conditions and in agroforestry models.

\section{Acknowledgements}

We are very grateful to Capes and FCAV-UNESP Campus of Jaboticabal for the grant of doctorate awarded; To the Polo Centro Norte - APTA for the support in the accomplishment of the work.

\section{REFERENCES}

[1] Abdo M T V, Valeri SV, Ferraudo AS, Martins A LM, Spatti
LR. 2017. Pioneer tree responses to variation of soil attributes in a tropical semi-deciduous forest in Brazil. Journal of Sustainable Forestry, 36[11]: 134-147.

[2] Fonseca RCB, Fonseca ICB. 2004. Utilização de métodos estatísticos multivariados na caracterização de mosaico sucessional em floresta semidecidual. Revista Árvore, Viçosa. 28(3): 351-359.

[3] Araújo MM, Longhi SJ, Brena DA, Barros PLC, Franco S. 2004. Análise de agrupamento de um fragmento de floresta estacional decidual aluvial, Cachoeira do Sul, RS, Brasil. Ciência Florestal, Santa Maria. 14 (1): 133-147.

[4] Kotchetkoff-Henriques O, Joly CA, Bernacci L. 2005. Relação entre solo e a composição florística de remanescentes de vegetação natural no município de Ribeirão Preto, SP, São Paulo. Revista Brasileira de Botânica, São Paulo. 28(3): 341-362.

[5] Araújo ARB. 2006. Fatores edáficos condicionantes na distribuição das espécies arbóreas em remanescentes de Floresta Estacional Semidecidual e Cerrado. Tese (Doutorado em Agronomia: Produção vegetal) - Faculdade de Ciências Agrárias e Veterinárias, Jaboticabal. 118 p.

[6] Rego N H. 2008. Variação da estrutura da vegetação arbórea em uma topossequencia num vale da Serra de Maracaju, Aquidauana, MS. Tese (Doutorado em Agronomia: Produção Vegetal) - Faculdade de Ciências Agrárias e Veterinárias, Jaboticabal. 105 p.

[7] Rodrigues RR, Nave AG. 2004. Heterogeneidade florística de Matas Ciliares. In: Rodrigues RR, Leitão Filho HF (Ed.) Matas Ciliares: conservação e recuperação. São Paulo: EDUSP. 2000, p. $45-71$.

[8] Leitão Filho HF. 1987. Considerações sobre a florística de florestas tropicais e subtropicais do Brasil. IPEF, Piracicaba. 35: 41-46.

[9] Jacomine PTK. Solos sob matas Ciliares. 2000. In: Rodrigues, R. R.; Leitão Filho, H. F. (Ed.). Matas cilares: conservação e recuperação. SP: EDUSP. 320 p.

[10] Tabanez AAJ, Viana VM, Dias A S. 1997. Conseqüências da fragmentação e do efeito de borda sobre a estrutura, diversidade e sustentabilidade de um fragmento de floresta de planalto de Piracicaba, SP. Revista Brasileira de Biologia, 57(1): 47-60.

[11] Abdo MTVN. Caracterização da vegetação arbórea e atributos do solo da Reserva Biológica de Pindorama, SP. [tese]. Jaboticabal, SP: Departamento de Produção Vegetal, Universidade Estadual Paulista "Júlio de Mesquita Filho; 2009. 
[12] Lepsch IF, Valadares JMAS.1976. Levantamento pedológico detalhado da Estação Experimental de Pindorama. Bragantia, Campinas. 35(2): 13-40.

[13] Comissão Nacional de Solos. 1960. Levantamento de reconhecimento dos solos do Estado de São Paulo. Rio de janeiro: Serviço Nacional de Pesquisas Agronômicas (Boletim12), 634p.

[14] EMBRAPA SOLOS. Sistema brasileiro de classificação de solos. Rio de Janeiro, 1999. 412 p.

[15] Mueller-Dombois D, Ellenberg H.1974. Aims and methods of vegetation ecology. New York: Willey. 574 p.

[16] Raij B, Cantarella H, Quaggio JH, Furlani AMC.1996. Recomendação de adubação e calagem para o Estado de São Paulo. 2.ed. Campinas: IAC. 285 p.

[17] Valeri SV, Politano W, Senô KCA, Barreto ALNM. 2003.
Manejo e recuperação florestal legislação, uso da água e sistema agroflorestais. Jaboticabal: FUNEP.180 p.

[18] Hair JF, Anderson RE, Tatham RL, Black W. 2005. Análise Multivariada de dados. 5.ed. Porto Alegre: Bookman.

[19] STATSOFT-STATISTICA: Data analysis software system: version 7. Tulsa: Statsoft, CD-ROM. 2007.

[20] Nobrega AMF, Valeri, SV, Paula RC, Silva AS, Rêgo NH. Uso da fitossociologia na avaliação da efetividade de restauração florestal em uma várzea degradada do Rio Mogi Guaçu, SP. Scientia Forestalis, Piracicaba, n. 75, p. 51-63, 2007.

[21] Gonçalves JLM, Raij B, Gonçalves JC. Florestais. In: Raij BV, Cantarella H, Quaggio JÁ, Furlani AMC, Eds. Recomendação de adubação e calagem para o estado de São Paulo. 2.ed. Campinas, Instituto Agronômico de Campinas, 1997. p. 247-259. (Boletim Técnico, 100). 